\title{
HUBUNGAN PENGETAHUAN DENGAN KETERAMPILAN IBU DALAM MENSTIMULASI MOTORIK KASAR ANAK UMUR 36 - 48 BULAN
}

\author{
Desak Gede Yenny Apriani ${ }^{1,2}$, Desak Made Firsia Sastra Putri ${ }^{1,2}$, Ni Kadek Ayu Pilgin Olganindi ${ }^{1,2}$ \\ ${ }^{1}$ S1 Keperawatan Ners, ${ }^{2}$ STIKES Advaita Medika Tabanan, \\ Korespondensi penulis: yennyapriani2004@gmail.com
}

\begin{abstract}
Abstrak
Latar belakang: Perkembangan adalah bertambahnya kemampuan fungsi tubuh yang lebih kompleks dalam pola yang teratur. Di masyarakat masih banyak orang tua yang kurang tahu tentang perkembangan anaknya, sehingga keterlambatan tidak dapat terdeteksi secara dini. Dengan pemberian stimulasi, keterlambatan perkembangan anak dapat dideteksi dan diintervensi secara dini.

Tujuan: Tujuan penelitian ini dilakukan untuk mengetahui hubungan tingkat pengetahuan dengan keterampilan ibu dalam menstimulasi motorik kasar anak umur 36-48 bulan.

Metode: Jenis penelitian yang digunakan asossiatif dengan model pendekatan cross sectional dan menggunakan variabel independent dan dependent. Pengumpulan data menggunakan lembar kuesioner. Setelah data terkumpul disajikan dalam tabel dan dianalisis dengan menggunakan uji statistik Spearman Rank.

Hasil: Hasil penelitian menunjukkan tingkat pengetahuan ibu tentang stimulasi motorik kasar paling banyak $37,1 \%$ pada kategori cukup dan keterampilan ibu menstimulasi motorik kasar paling banyak $35,1 \%$ pada kategori cukup dimana $(r=0,866, p=0,000)$ sehingga terdapat hubungan yang signifikan antara tingkat pengetahuan dengan keterampilan ibu dalam menstimulasi motorik kasar.

Simpulan: tingkat pengetahuan memiliki hubungan yang kuat dengan keterampilan ibu dalam menstimulasi motorik kasar anak. Informasi tentang stimulasi motorik kasar dapat menjadi suatu upaya bagi peningkatan pengetahuan dan keterampilan ibu yang dapat dilakukan melalui penyuluhan oleh tenaga kesehatan.
\end{abstract}

Kata kunci: Anak umur 36-48 bulan,Keterampilan, Stimulasi perkembangan, Tingkat pengetahuan

\section{Pendahuluan}

Anak adalah bagian dari generasi muda sebagai salah satu sumber daya manusia yang merupakan potensi dan penerus cita-cita perjuangan bangsa yang memiliki peran strategis dan mempunyai ciri dan sifat khusus memerlukan pembinaan perlindungan dalam rangka menjamin pertumbuhan dan perkembangan fisik, mental, sosial secara utuh, serasi, selaras dan seimbang. Jadi harus dipastikan balita mengalami perkembangan yang sesuai agar tercipta generasi yang berkualitas apalagi jumlah balita di Indonesia sangat besar (Kusbiantoro, 2015).

Dalam masa balita merupakan masa kritis bagi anak sehingga hendak mendapatkan perhatian yang khusus dari orang tua karena keberhasilan perkembangan motorik tergantung dari pengasuhan orang tua. Namun kenyataannya, di masyarakat banyak orang tua yang kurang tahu mengenai perkembangan anaknya, apakah anaknya sudah berkembang sesuai umurnya atau tidak sehingga keterlambatan tidak dapat terdeteksi secara dini. Mengingat status pendidikan dan pengetahuan keluarga mempengaruhi perkembangan anak sehingga besar kemungkinan dapat berpengaruh terhadap perkembangan (Aziz, 2018).

Dewasa ini masalah tumbuh kembang anak merupakan masalah yang perlu diketahui atau dipahami sejak konsepsi 
hingga dewasa yang menurut World Health Organization (WHO) sampai usia 18 tahun, sedangkan menurut Undang-undang Kesejahteraan anak RI No. 4 tahun 1979 sampai dengan usia 21 tahun sebelum menikah (Aziz, 2018). Menurut data (DinKes) Dinas Kesehatan Tabanan tahun 2018 didapatkan gangguan perkembangan motorik kasar sebesar $(19,7 \%)$ dan gangguan perkembangan motorik halus sebesar $(16,2 \%)$ diantaranya berusia 1-3 tahun yang mengalami gangguan perkembangan. Masih tingginya angka kejadian gangguan pertumbuhan dan perkembangan pada anak balita khususnya gangguan perkembangan motorik didapatkan $23,5(27,5 \%)$ / 5 juta anak mengalami gangguan (UNICEF, 2019).

Anak prasekolah di Kabupaten Tabanan dilaporkan 7224 orang $(45,5 \%)$ di antaranya berusia 3-4 tahun dan sebanyak 365 orang $(5,1 \%)$ anak mengalami keterlambatan perkembangan sosial, dan 85 orang $(2,8 \%)$ anak mengalami masalah kecerdasan interpersonal (Dinkes Provinsi Bali, 2019).

Berdasarkan hasil study pendahuluan di Desa Abiantuwung, wilayah kerja Puskesmas Kediri I, menurut laporan yang tercatat pada tahun 2019 terdapat 562 balita, dengan jumlah balita umur 36-48 bulan yaitu 213 balita. Dari 213 balita tersebut 35 balita mengalami keterlambatan motorik kasar dengan bentuk keterlambatan seperti belum bisa berjalan, meniru gerakan sederhana, berlari, menulis, 24 balita mengalami keterlambatan motorik halus dengan bentuk keterlambatan seperti belum bisa memakai baju sendiri, makan tanpa bantuan, memotong gambar, melempar bola kecil, 12 balita mengalami keterlambatan bicara dan bahasa serta 16 balita mengalami keterlambatan dalam perkembangan sosialisasi dan kemandirian. Dari 6 orang ibu yang peneliti wawancarai terdapat 4 orang ibu yang mengatakan masih belum tahu cara menstimulasi motorik kasar anak, dan 2 orang ibu yang sudah tahu cara menstimulasi anaknya sesuai dengan umur.

\section{Metode Penelitian}

Populasi Penelitian, populasi adalah keseluruhan obyek yang diteliti (Notoatmodjo, 2018). Populasi dalam penelitian ini adalah seluruh ibu yang mempunyai anak normal umur 36-48 bulan yang ada di Abiantuwung wilayah kerja Puskesmas Kediri I sebanyak 126 balita.

Sampel Penelitian, sampel adalah sebagian dari keseluruhan objek yang diteliti dan dianggap mewakili seluruh populasi (Notoatmojo, 2018). Sampel dalam penelitian ini adalah ibu yang memiliki anak usia 36-48 bulan di desa Abiantuwung dengan perkembangan anak yang mengalami keterlambatan sebanyak 97 orang.Teknik sampling adalah cara-cara yang ditempuh dalam pengambilan sampel agar memperoleh sampel yang benar-benar sesuai dengan keseluruhan obyek penelitian (Nursalam, 2016).

Pada penelitian ini teknik sampling yang digunakan adalah Probability Sampling yaitu dengan menggunakan Proportionate Stratified Random Sampling adalah teknik pengambilan sampel yang digunakan pada populasi yang tidak homogen dan berstrata secara proporsional atau tehnik yang dilakukan untuk menentukan sampel yang akan diambil sebagai subjek penelitian (Sugiono, 2018). Data yang diambil adalah data primer, yaitu data yang diambil langsung dari responden (sampel yang diteliti).

\section{Hasil dan Pembahasan}

Selama kurun waktu penelitian dari proses pengumpulan data didapatkan responden sebanyak 97 orang yang memenuhi kriteria penelitian. Pada subyek penelitian akan diuraikan mengenai karakteristik responden berdasarkan umur, pendidikan, pekerjaan, dan perolehan informasi mengenai stimulasi motorik kasar yang telah diteliti dan didistribusikan ke dalam tabel distribusi. 
Tabel 1. Distribusi Frekuensi Responden berdasarkan Umur di desa Abiantuwung wilayah kerja Puskesmas Kediri I pada bulan Juli - Agustus 2020

\begin{tabular}{ccc}
\hline Umur Responden & Frekuensi (n) & Persentase (\%) \\
\hline$<20$ Tahun & 10 & 12,37 \\
\hline $20-35$ Tahun & 68 & 70,10 \\
\hline$>35$ Tahun & 19 & 17,52 \\
\hline Total & 97 & 100,0 \\
\hline
\end{tabular}

Tabel 2. Distribusi Frekuensi Responden berdasarkan Pendidikan responden yang ada di desa Abiantuwung wilayah Kerja Puskesmas Kediri I pada bulan Juli - Agustus 2020.

\begin{tabular}{ccc}
\hline Pendidikan Responden & Frekuensi (n) & Persentase (\%) \\
\hline SD & 8 & 8,24 \\
\hline SMP & 29 & 30,92 \\
\hline SMA & 45 & 46,39 \\
\hline Akademi/PT & 15 & 14,43 \\
\hline Total & 97 & 100,0 \\
\hline
\end{tabular}

Tabel 3. Distribusi Frekuensi Responden berdasarkan pekerjaan di desa Abiantuwung wilayah Kerja Puskesmas Kediri I pada bulan Juli - Agustus 2020

\begin{tabular}{ccc}
\hline Pekerjaan Responden & Frekuensi (n) & Persentase (\%) \\
\hline IRT & 47 & 48,45 \\
\hline Buruh/Petani & 14 & 14,43 \\
\hline Pedagang & 18 & 18,56 \\
\hline Swasta & 10 & 10,31 \\
\hline PNS & 8 & 8,25 \\
\hline Total & 97 & 100,0
\end{tabular}

Tabel 4. Distribusi Frekuensi Responden berdasarkan jumlah anak di desa Abiantuwung wilayah Kerja Puskesmas Kediri I pada bulan Juli - Agustus 2020.

\begin{tabular}{ccc}
\hline Jumlah Anak Responden & Frekuensi (n) & Persentase (\%) \\
\hline 1 orang & 32 & 32,99 \\
\hline 2 orang & 44 & 45,36 \\
\hline 3 orang & 16 & 16,49 \\
\hline 4 orang & 5 & 5,15 \\
\hline 5 orang/lebih & 0 & 0,00 \\
\hline Total & 97 & 100,0 \\
\hline
\end{tabular}

Tabel 5. Distribusi Frekuensi Responden berdasarkan pernah atau tidak mendapatkan informasi mengenai Stimulasi Motorik Kasar di desa Abiantuwung pada bulan Juli - Agustus 2020.

\begin{tabular}{ccc}
\hline Responden Mendapatkan Informasi & Frekuensi (n) & Persentase (\%) \\
\hline Pernah & 97 & 100,0 \\
\hline Tidak Pernah & 0 & 0,00 \\
\hline Total & 97 & 100,0 \\
\hline
\end{tabular}

Tabel 6. Distribusi Frekuensi Responden berdasarkan sumber informasi yang didapatkan mengenai Stimulasi Motorik Kasar pada bulan Juli - Agustus 2020.

\begin{tabular}{ccc}
\hline Sumber Informasi Responden & Frekuensi (n) & Persentase (\%) \\
\hline Media Elektronik & 41 & 42,26 \\
\hline Teman/Keluarga & 12 & 12,37 \\
\hline Media Massa & 13 & 13,40 \\
\hline Tenaga Kesehatan & 31 & 31,95 \\
\hline Total & 97 & 100,0 \\
\hline
\end{tabular}


Tingkat pengetahuan sangat dipengaruhi oleh beberapa faktor yaitu faktor umur, pendidikan, pekerjaan, dan perolehan informasi. Berdasarkan hasil analisa data, dari 97 responden tampak bahwa tingkat pengetahuan ibu tentang stimulasi motorik kasar yang ada di desa Abiantuwung paling banyak berada dalam kategori cukup yaitu 36 responden $(37,1 \%)$.

Berdasarkan hasil penelitian, diketahui bahwa paling banyak yaitu 34 responden $(35,1 \%)$ memiliki keterampilan yang cukup dalam pemberian stimulasi motorik kasar. Selain pengetahuan ibu yang cukup dalam menstimulasi motorik kasar anak, keterampilan ibu dalam pemberian stimulasi motorik kasar juga didukung oleh informasi yang diterima ibu baik dari media elektronik, media cetak maupun langsung dari petugas kesehatan. Dengan demikian keterampilan ibu untuk memberikan stimulasi motorik kasar juga semakin baik dalam pemenuhan kebutuhan perkembangan anak. Pemberian stimulasi perkembangan memberikan sebuah pengalaman emosional yang unik bagi ibu dan bagi anak selama masa perkembangan disamping dapat memberikan keuntungan kesehatan bagi ibu dan anak.

Dari 97 responden yang berpartisipasi pada penelitian ini terdapat 20 responden $(20,6 \%)$ memiliki pengetahuan cukup mengenai stimulasi motorik kasar anak dan keterampilan yang cukup dalam menstimulasi motorik kasar anak. Berdasarkan hasil penelitian tersebut, didapatkan bahwa pengetahuan berhubungan positif dengan keterampilan dalam menstimulasi, yang artinya semakin baik pengetahuan seseorang, maka semakin baik pula keterampilan yang dimiliki.

\section{Simpulan}

Pada tingkat pengetahuan ibu terdapat sebanyak 59 orang ibu dalam kategori cukup dan baik yang memiliki pengetahuan tentang menstimulasi motorik kasar anak. Pada keterampilan ibu terdapat sebanyak 69 orang ibu dalam kategori cukup dan baik yang memiliki keterampilan tentang menstimulasi motorik kasar anak.
Dari hasil uji statistik dapat disimpulkan bahwa terdapat hubungan yang positif dan signifikan antara tingkat pengetahuan dengan keterampilan ibu dalam menstimulasi motorik kasar anak usia 36-48 bulan.

\section{Referensi}

Agung, A.A. 2019. Metodelogi Penelitian. Rineka Cipta, Jakarta

Arikunto, Suharsimi. 2010. Prosedur Penelitian. Jakarta : Rineka Cipta

Aziz. 2018. "Perkembangan Anak". http://www.info-sehat.com. Diakses tanggal 12 November 2019.

Dit. Bina Kes Kel,2016. Pedoman Deteksi Dini Kelainan Tumbuh Kembang Balita, Jakarta.

Judarwanto, Widodo. 2018."Stimulasi Keterampilan Motorik Anak Sejak Dini".

http://childrenfootclinic.wordpress.co m Diakses tanggal 12 November 2019

Fitri. 2018. "Pengertian Anak Tinjauan Secara Kronologis Dan Psikologis." http://duniapsikologi.dagdigdug.com/2 008/11/19/pengertian-anak-tinjauansecara-kronologis-dan-psikologis. Diunduh tanggal 12 November 2019

Hasanah \& Ansori, 2019. Perkembangan Motorik Pada Anak. Jakarta: Erlangga.

Hurlock, Elizabeth.B. 2019. Perkembangan Anak. Jakarta: Erlangga.

Kementrian Kesehatan R.I. 2019. Pedoman Pelaksanaan Stimulasi, Deteksi dan Intervensi Dini Tumbuh Kembang Anak. Jakarta : Kementrian Kesehatan RI.

Kusbiantoro, 2015. Pengertian Anak. Jakarta: Erlangga.

Maryunani, dkk. 2018. Ilmu Kesehatan Anak dalam Keperawatan. Jakarta: Trans Info Media.

Ngatimin 2017, Pengertian Pengetahuan. Jakarta: Erlangga.

Notoatmodjo, S. 2018. Kesehatan Masyarakat Ilmu dan Seni. Jakarta: PT. Rineka Cipta.

Notoatmodjo 2018. Metodelogi Penelitian Kesehatan. Jakarta: PT. Rineka Cipta. 
Nursalam. 2011. Kerangka Kerja Penelitian. Jakarta: Salemba Medika.

Nursalam. 2016. Konsep dan Penerapan Metodologi Ilmu Keperawatan. Jakarta: Salemba Medika.

Riwidikdo Handoko, S.Kep. 2018. Statistik Kesehatan. Jogjakarta: Mitra Cendikia Press.

Schmidt, Richard A. 2019. Motor Learning and Performance: From Principle into Practice. Human Kinetics. Champaign, IL.

Setyowati dalam Etri Rustina. 2019. "Pengertian Stimulasi". http://parentingislami.wordpress.com. Diakses tanggal 12 November 2019

Singer, Robert N. (2019). Motor Learning and Human Performance: An Application to Motor Skills and Movement Behaviors. Macmillan Pub. New York

Soetjiningsih. 2018. Tumbuh Kembang Anak. Jakarta: EGC.

Soetjiningsih. 2018. "Faktor-faktor yang Mempengaruhi Perkembangan Anak". http://www.psychologymania.com/201 2. Diakses tanggal 23 November 2018

Sugiono. 2010. Metode Penelitian Pendidikan. Bandung: Alfabeta.

Tagor.R.A, I.F. Rahmani, E.N Lubis, I.M Pattinama, E. Bergita, (2016), Dari A sampai $Z$ Tentang Perkembangan Anak, Buku Pegangan untuk Pasangan Muda, Ayah Bunda 2016

Tim Penyusun Kamus Pusat. (2018). Kamus Besar Bahasa Indonesia. Jakarta: Balai Pustaka 